UDC $519.6+612.1$

\title{
Novel monitoring system for quantitative estimation of efficient medical treatment of diseases based on dielectric properties of blood samples
}

\author{
L.V. Batyuk ${ }^{1}$, N.N. Kizilova ${ }^{2}$ \\ ${ }^{1}$ Kharkiv National Medical University, Kharkiv, Ukraine \\ ${ }^{2}$ V.N. Karazin Kharkiv National University, Kharkiv, Ukraine \\ e-mail:n.kizilova@gmail.com
}

\begin{abstract}
A new system for monitoring the effects of radiation and chemotherapy on patients with cancer and some other severe diseases based on the changes in the dielectric characteristics of their blood samples before and after the treatment using a preorganized system of knowledge on the cancer dynamics, statistical long-term data processing either in the individual or for different cancer types, novel mathematical models and computations on them for interpreting the measurement data is presented. The elaborated system allows accumulating, storing and retrieving data for primary and repeated data processing, the real time decision making on the efficiency/inefficiency of the treatment procedures, and planning future treatment procedures.
\end{abstract}

Key words: monitoring system, oncology, chemotherapy, radiotherapy, efficiency, mathematical modeling, dielectric properties, medical diagnostics.

В работе представлена новая система мониторинга результатов влияния радиационной и химиотерапии на пациентов c онкологическими заболеваниями и ряда других заболеваний на основании изменения диэлектрических характеристик проб крови пациентов до и после лечения на основе предварительно организованной системы знаний о динамике развития онкологического заболевания, статистической обработки данных длительных измерений как у данного пациента, так и по видам заболеваний, специально разработанных математических моделей и результатов численных расчетов по ним для интерпретации экспериментальных данных. Разработанная система позволяет накапливать, хранить и извлекать данные для первичной и повторной статистической обработки информации, в реальном времени принимать решения об эффективности/неэффективности терапевтических процедур и планировать последующие лечебные мероприятия.

Ключевые слова: система мониторинга, онкология, химиотерапия, радиотерапия, эффективность, математические моделирование, диэлектрические свойства, медицинская диагностика.

У роботі представлена нова система моніторингу результатів впливу радіаційної та хіміотерапії на пацієнтів 3 онкологічними захворюваннями та ряду інших хвороб (ішемічний, геморагічний інсульт та інші) на основі зміни діелектричних характеристик проб крові пацієнтів до і після лікування з використанням попередньо організованої системи знань про динаміку онкологічних захворювань, статистичної обробки даних багаторічних вимірювань як у конкретного пацієнта, так і за типом хвороби, а також спеціально розроблених математичних моделей і результатів чисельних розрахунків для інтерпретації експериментальних даних. В першому розділі статті наданий детальний огляд сучасної літератури 3 досягнень сучасних індивідуальних фізіологічних та математичний моделей, автоматичних комп'ютерних систем збору медичних даних, результатів чисельних розрахунків за математичними моделями 3 урахуваннями реальної індивідуальної 3-вимірної геометрії досліджуваної системи, даних безпосередніх вимірювань швидкостей та тисків в окремих артеріальних сегментах, а також результатів чисельних розрахунків, у тому числі інтегральних параметрів, а саме об’ємних витрат крові в судинах та осереднених значень тисків. В другому розділі наведені математичні моделі, які є складниками запропонованої системи моніторингу, діагностики та лікування онкологічних захворювань на основі електрофізичних параметрів стандартних проб крові пацієнта за допомогою вимірювань діелектричних показників проби в зовнішньому електромагнітному випромінюванні СВЧдіапазону при широкому варіюванні температури зразка в діапазоні $\mathrm{T}=0-56 \mathrm{C}$.

Розроблена система дозволяє накопичувати, зберігати та видавати дані для первинної та повторної статистичної обробки інформації, в реальному часі приймати рішення про ефективність/неефективність терапевтичних процедур і планувати подальші лікувальні заходи.

Ключові слова: система моніторингу, онкологія, хіміотерапія, радіотерапія, ефективність, математичні моделювання, діелектричні властивості, медична діагностика.

\section{Introduction}

Revolutionary technologies being currently developed in physics, chemistry, material and computer sciences are rapidly changing our life and healthcare. During the last decades many novel approaches to medical diagnostics, surgery planning with computer-based systems have changed the quality of medical care and promoted development of patient-specific medicine using complex individual mathematical models, automated medical data analysis systems, omics-based studies, and decision making algorithms with artificial intelligence (AI) [1-3]. Digital technologies are promoting the elaboration of novel materials for bone implants, orthodontic units and teeth restoration which are based on the computer-assisted mechanical analysis of the individual 3D models. Blood flow simulations with 
computational fluid dynamics (CFD) in the patient-specific cardiovascular models allow estimation of the stenosis severity and decision making on the number of stents needed for the blood flow normalization [4]. Moreover, electromagnetic, acoustic, optical and other physical properties of tissues carry valuable diagnostic information [5]. Since blood is the most movable fluid that passes through any organ and tissue, in the case of cancer, blood is strongly influenced by the products of the cancer cell metabolism and tissue decay that changes chemical and physical properties of the red blood cells (RBC) and blood plasma [6]. Such changes can be observed even at the early stages of the cancer development and may serve as an excellent test for early diagnosis of cancer [7]. Since measurements and interpretations of mechanical, electric and other physical properties require coordinated efforts of engineers, mechanics, biologists, mathematicians and medical specialists; the modern medicine is becoming an interdisciplinary science.

Another dimension to the healthcare is added by One Health $(\mathrm{OH})$ concept that is a new health policy framework of the XXI Century. The OH concept treats human health as connected with animal health and bacterial maps, environmental conditions (food and water quality, pollutions, etc.), economy and other factors $[8,9]$. It is well recognized that the cancer diseases are mostly determined by environmental, economic and other factors included into the $\mathrm{OH}$ concept. Currently a breakthrough in cancer diagnosis has been demonstrated by high-fidelity cancer detection on medical images using AI $[1,2,10]$. The AI code based on convolution neural network (CNN) [11] has correctly recognized skin cancer in $95 \%$ cases, while the international team of 58 experienced dermatologists from 17 countries have succeeded in $86,6 \%$ cases [12]. AI based on GoogLeNet Inception CNN has demonstrated better abilities in recognition of lung cancer on the whole-slide images of human chest than an international team of recognized pulmonologists [13]. Reinforcement Learning algorithms have been trained for predicting individual optimal dosing in treatment of brain tumor [14].

Recently deep learning algorithms have been successfully trained using data from 284335 cardiovascular patients and validated on two independent datasets of 12026 and 999 patients with successful prediction of cardiovascular risks based on the image analysis of their retinal fundus photographs [15].

Therefore, AI demonstrated promising perspectives in analysis, recognition and classification of patterns on medical images, integrated arrays of different omic data including the incomplete datasets. The physicians could be augmented by AI creating the expert-in-the-loop system that is considered a new approach in the personal healthcare [3]. Information technologies and multidisciplinary approaches in cancer diagnosis and treatment are the main components of patient-specific predictive oncology. In this study such a system for monitoring human health and quantitative estimation of efficiency of the cancer treatment based on detailed measurements of dielectric properties of blood samples is presented.

\section{Dielectric properties of biological materials}

Biological cells and tissues are characterized by surface electric charge produced by the charged proteins, dissociation of the surface molecules, and adsorption of ions from the interstitial fluids or blood plasma. The charged particles form several compact and less compact layers around the cells in water-based solvents. In the external and internal electric fields (i.e. produced by heart, skeletal and smooth muscle contractions, electric signal propagation along nerve fibers and brain activity) the electric layers are polarized changing the dielectric permittivity $\varepsilon=\varepsilon^{\prime}+i \varepsilon^{\prime \prime}$ of biological cells and tissues [16]. The real part $\varepsilon^{\prime}$ corresponds to static dielectric permittivity, while $\varepsilon^{\prime \prime}$ corresponds to the energy loss in the material being an imperfect dielectric. The dielectric loss $\varphi_{\varepsilon}=a \tan \left(\varepsilon^{\prime \prime} / \varepsilon^{\prime}\right)$ characterizes the amount of the energy converted into heat due to electric conductivity and dielectric losses. Dielectric permittivity of blood increases with the concentration of RBCs and blood plasma proteins.

The dielectric parameters of biological materials shows the dependence on the frequency $\omega$ of the applied electric field (dispersion) in the form $\varepsilon^{\prime}(\omega), \varepsilon^{\prime \prime}(\omega)$. The frequency dependencies for dielectric permittivity with single relaxation time $\tau$ (Debye model) have the form [15]

$$
\varepsilon^{\prime}(\omega)=\varepsilon_{\infty}+\frac{\varepsilon_{0}-\varepsilon_{\infty}}{(1+\omega \tau)^{2}}, \quad \varepsilon^{\prime \prime}(\omega)=\frac{\omega \tau\left(\varepsilon_{0}-\varepsilon_{\infty}\right)}{(1+\omega \tau)^{2}},
$$

where $\varepsilon_{\infty}$ and $\varepsilon_{s}$ are permittivity measured at high $\omega \tau_{n} \gg>1$ (the $\mathrm{THz}$ frequency range) and low $\omega \tau<<1$ frequency ranges, $\varepsilon_{0}$ corresponds to the steady electric field. 
The modified Cole-Cole dispersion model is described by the generalized equation

$$
\varepsilon(\omega)=\varepsilon_{\infty}+\frac{\varepsilon_{d c}-\varepsilon_{\infty}}{1+(i \omega \tau)^{1-\alpha}}+\frac{\sigma_{i}}{i \omega \varepsilon_{0}},
$$

where $\alpha$ is the Cole-Cole parameter.

The dispersion relation for electric conductivity $\sigma$ of the sample may be written then as [15]

$$
\sigma(\omega)=\omega^{2} \tau \frac{\sigma_{\infty}-\sigma_{0}}{1+(\omega \tau)^{2}} .
$$

The curves $\varepsilon^{\prime}(\omega), \varepsilon^{\prime \prime}(\omega)$ can be measured by dielectric spectroscopy (DS) technique proved to be a useful approach for analyzing heterogeneous systems, especially biological cell suspensions and tissues [15]. Nowadays the DS technique can be applied to a single cell, which makes the theoretical analysis relatively simple because complex electrical interactions between cells need not to be accounted for. The proposed system of monitoring is based on the DS measurements on diluted suspensions of human RBC and the data analyses based on (1)-(3).

\section{The monitoring system components}

\subsection{The dielectric spectroscopy unit}

The dielectric parameters of the tissue samples have been measured by the method of microwave dielectrometry using a cylindrical resonator at a working frequency $\mathrm{f}=9.2 \mathrm{GHz}$ in the temperature range $\mathrm{T}=2-45{ }^{\circ} \mathrm{C}$ that allows recording the structural changes in the electric layers and hydrated shells of the cells at a molecular level by the ratio between free and bound water contents [15]. For $\varepsilon^{\prime}$ measurements, the sample has been collected in a capillary ( $2 \mathrm{~mm}$ in diameter), placed in the resonator, and a shift of the resonant frequency between the natural frequency of the resonator and the resonator with the sample has been recorded. The values $\varepsilon^{\prime}$ and $\varepsilon^{\prime \prime}$ have been calculated from the gradient curves obtained for substances with known values $\varepsilon^{\prime}$ and $\varepsilon^{\prime \prime}$. The value $\varepsilon^{\prime \prime}$ has been corrected for electrical conductivity due to the presence of inorganic ions in the medium. The electrical conductivity of the samples has been measured by a bridge method at $\mathrm{f}=1 \mathrm{kHz}$ at room temperature. The error in the obtained values do not exceed \pm 0.2 for $\varepsilon^{\prime}$ and \pm 0.5 for $\varepsilon^{\prime \prime}$. The temperature of the samples in the capillary has been measured with a copper-constantan thermocouple with an accuracy of $\pm 0.1{ }^{\circ} \mathrm{C}$. The room temperature has been $20.0{ }^{\circ} \mathrm{C}$, and the sample has been cooled/heated by keeping it in ice/hot water accordingly.

The measurement procedure has been as follows. A venous blood sampling $(2 \mathrm{ml})$ has been performed on an empty stomach. The collected blood has been stabilized with an anticoagulant $(0.1 \mathrm{ml}$ of heparin solution with 5000 IU activity). Then the erythrocyte fraction has been separated from the plasma by centrifugation (three times) at $3000 \mathrm{~g}$ (10 minutes per centrifugation cycle) with sodium phosphate buffer $\left(0.15 \mathrm{M} \mathrm{NaCl}, 0.02 \mathrm{M} \mathrm{Na}_{2} \mathrm{HPO}_{4} / \mathrm{NaH}_{2} \mathrm{PO}_{4}, \mathrm{pH}=7.4\right)$. Then a suspension of cells has been prepared in the same buffer with natural concentrations $4.8 \times 10^{3}$ cells $/ \mathrm{mm}^{3}$ ). The portion of the suspension has been placed into the unit for measurements of $\varepsilon^{\prime}$ and $\varepsilon^{\prime \prime}$ at different temperatures. The measured values have been submitted to the database.

\subsection{Database}

A convenient structure of the database has been elaborated. Each record related to a single patient or volunteer contains encrypted personal information; anamnesis with the prescribed treatment(s) and the treatment results; previously obtained clinical and biochemical blood examination results; current diagnosis and $\varepsilon^{\prime}(\mathrm{T})$ and $\varepsilon^{\prime \prime}(\mathrm{T})$ curves measured in the dielectric spectroscopy unit.

Currently, the datasets for healthy donors (67 records), patients with breast and lung cancer before and after chemical and/or X-ray therapy (78 records), patients with ischemic and haemorrhagic stroke before and after treatment ( 84 records), diabetes mellitus before and after treatment ( 53 records) are collected in the database.

\subsection{Statistical analysis core}

The data collected in the database have been thoroughly processed by different statistical methods (regression, correlation, factor analysis). The most important dependencies have been obtained and the 
main differences between healthy donors and patients have been determined. Based on the statistical data, it has been shown that $[6,7,15]$ :

1) The dielectric parameters are important non-specific indexes of the disease, the disease stage and the treatment success;

2) The differences in the $\varepsilon^{\prime}(\mathrm{T})$ and $\varepsilon^{\prime \prime}(\mathrm{T})$ curves between the healthy blood samples and the patients' blood samples increase with progression of the disease;

3) In cases of successful treatment, the $\varepsilon^{\prime}(\mathrm{T})$ and $\varepsilon^{\prime \prime}(\mathrm{T})$ curves become closer to the healthy ones;

4) The observed regularities are similar in the RBC and RBC ghost suspensions; therefore the changes in the dielectric parameters due to both disease progressing and treatment success are determined by the changes in the RBC membranes;

5) Since the dielectric measurements have been conducted in the TGz frequency when the water molecules are movable only, the hydration shells of the RBC and RBC ghosts can be responsible for the measured differences, therefore, the thickness and density of the hydration shells can be considered as the most informative indexes of the disease stage and the treatment success.
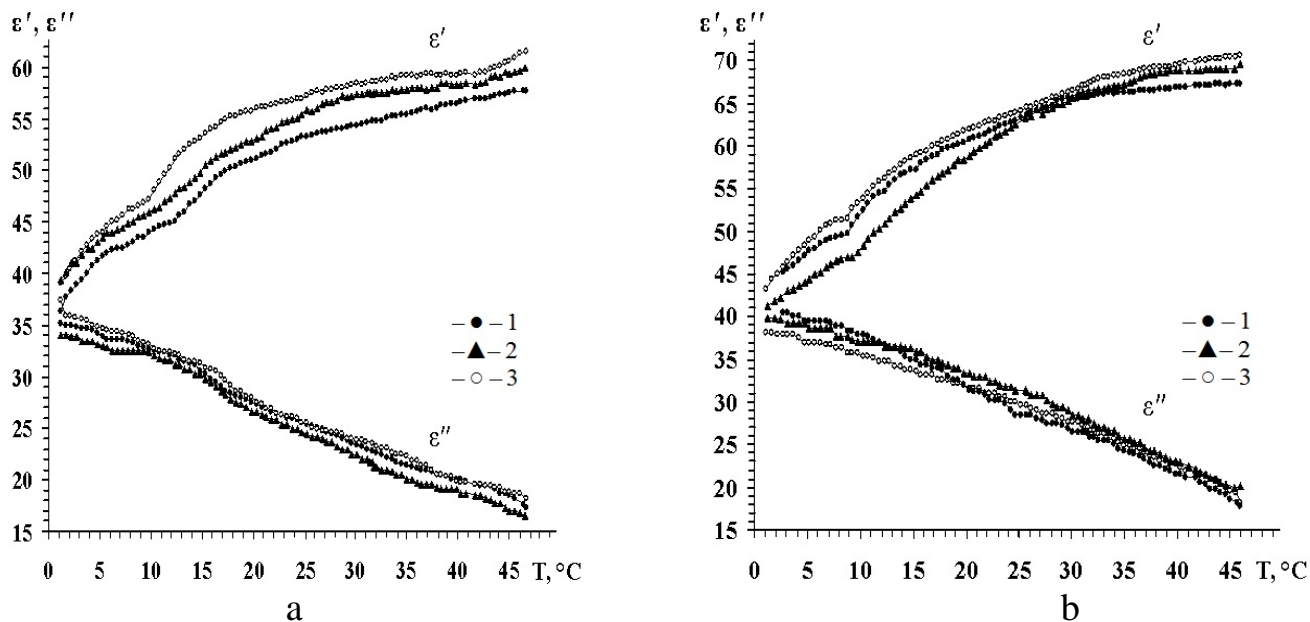

Fig.1 Dependencies $\varepsilon^{\prime}(T)$ and $\varepsilon^{\prime \prime}(T)$ of RBC suspensions (a) and RBC ghosts (b): 1 - healthy donors, 2 - breast cancer, 3 - lung cancer

\section{The monitoring system and its first implementation results}

The components described in the previous chapter are combined by the feedback connections into the novel approach for the computer-assisted decision making in individual medical diagnostics, treatment planning and result estimation (Fig.2).

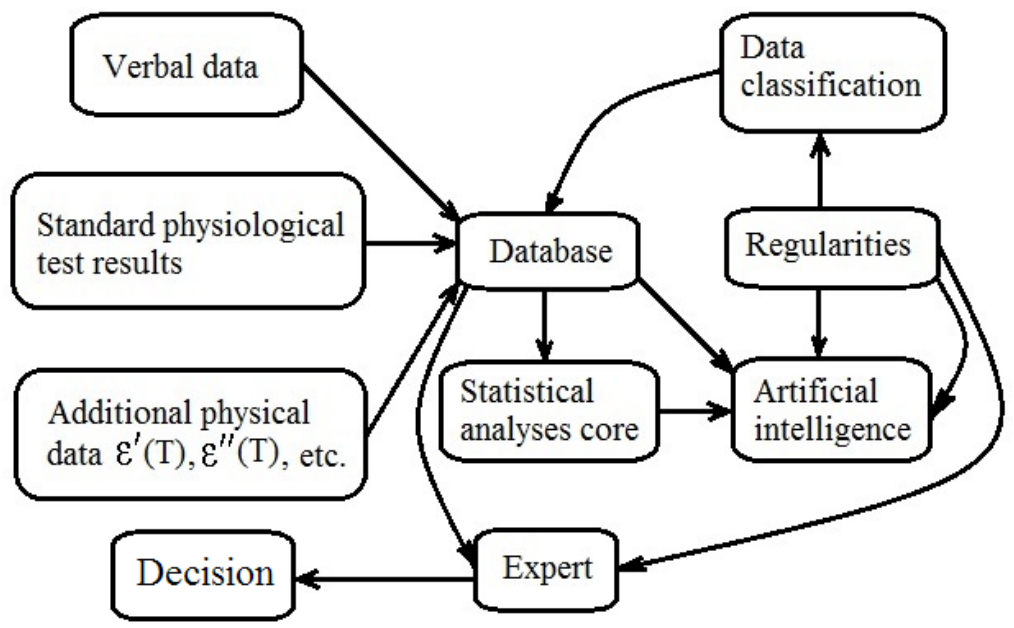

Fig.2 The monitoring system scheme 
The monitoring system could be run by AI which will increase the diagnostic and treatment ability of the system. As shown with the AI algorithms used for the skin [12] and lung [13] cancer diagnostics, retina photographs based cardiovascular risks prediction [15], the AI algorithms trained on the combination of verbal (age, gender, smoking status, etc.), numerical (blood pressure, blood sample examinations, and other standard physiological test results), and additional dielectric $\varepsilon^{\prime}(\mathrm{T})$ and $\varepsilon^{\prime \prime}(\mathrm{T})$ curves can be helpful in the decision making by the expert-in-loop system.

The collected medical data are not sufficient for deriving any global conclusions on the statistical regularities on the type of disease or individual treatment prescription. They are insufficient for training of AI and its validation as well. The results obtained on the datasets described in the paragraph 3.2, have revealed that variations of the $\varepsilon^{\prime}$ and $\varepsilon^{\prime \prime}$ values at different temperatures in healthy donors and cancer patients are statistically similar, and the dielectric properties of RBC and their membranes can be used as a non-specific cancer diagnostic parameter and a treatment success indicator.

\section{Conclusions}

A new monitoring system for cancer diagnosis and quantitative estimation of efficient medical treatment of cancer disease based on the results of the standard medical tests and additional measurements of dielectric parameters of blood samples in the wide temperature range from $\mathrm{T}=0 \mathrm{C}$ to the near protein denaturation temperatures $\mathrm{T} \sim 50 \mathrm{C}$ has been developed and tested. The system is proposed for further validation and implementation for more accurate early diagnostics of cancer and other diseases as well as for quantitative estimation of treatment success. Based on the collected database for the healthy donors, the patients with breast and lung cancer before and after chemical and/or X-ray therapy, the patients with ischemic and haemorrhagic stroke and diabetes mellitus before and after treatment, it has been shown that the real and imaginary parts of the dielectric permittivity of the $\mathrm{RBC}$ and $\mathrm{RBC}$ ghosts suspensions can be considered as important non-specific indexes of the disease and its stage. The same index can be used for quantitative estimation of the treatment success.

\section{REFERENCES}

1. K. Yu, A.L. Beam, I.S. Kohane, "Artificial intelligence in healthcare", Nature Biomedical Engineering, Vol. 2, pp. 719-731, 2018.

2. C.J. Lynch, C. Liston, "New machine-learning technologies for computer-aided diagnosis", Nature Medicine, Vol. 24, pp. 1304-1305, 2018.

3. D. Girardi, J. Küng, R. Kleiser, M. Sonnberger, D.C. Johannes, T.A. Holzinger, "Interactive knowledge discovery with the doctor-in-the-loop: a practical example of cerebral aneurysms research", Brain Informatics, Vol.3, pp. 133-143, 2016.

4. N. Kizilova, "Diagnostics of Coronary Stenosis: Analysis of Arterial Blood Pressure and Mathematical Modeling", In: Biomedical Engineering Systems and Technologies. Springer Series on Communications in Computer and Information Science. Plantier, G., Schulz, T., Fred, A., Gamboa, H. (Eds.), pp. 299-312, 2015.

5. N. Kizilova, "Electromagnetic properties of blood and its interaction with electromagnetic fields", In: Advances in Medicine and Biology. Vol.137. L.V. Berhardt (ed.) NOVA Sci. Publ., pp. 1-74, 2019.

6. L. Batyuk, N. Kizilova, "Dielectric properties of red blood cells for cancer diagnostics and treatment", AS Cancer Biology, Vol. 2(10), pp. 55-60, 2018.

7. L. Batyuk, N. Kizilova, V. Berest, "Investigation of antiradiation and anticancer efficiency of nanodiamonds on rat erythrocytes", In: Nanomaterials: Application \& Properties, pp. 04NB23, 2017.

8. P. Kingsley, E.M. Taylor, "One Health: competing perspectives in an emerging field", Parasitology, Vol. 144(1), pp. 7-14, 2017.

9. J. Zinnstag, E. Schelling, D. Waltner-Toews, M. Whittaker, M. Tanner (eds), One Health: the theory and practice of integrated health approaches, CAB International, 2015.

10. F. Azuaje, "Artificial intelligence for precision oncology: beyond patient stratification", Nature Precision Oncology, Vol. 3, pp. 6-11, 2019, doi:10.1038/s41698-019-0078-1.

11. W. Rawat, Z. Wang. "Deep convolutional neural networks for image classification: a comprehensive review", Neural Computation, Vol. 29, pp. 2352-2449, 2017. 
12. A. Forschner, U. Keim, M. Hofmann, I. Spänkuch, D. Lomberg, B. Weide, I. Tampouri, T. Eigentler, C. Fink, C. Garbe, H.A. Haenssle, "Diagnostic accuracy of dermatofluoroscopy in cutaneous melanoma detection: results of a prospective multicentre clinical study in 476 pigmented lesions", British Journal of Dermatology, Vol.179(2), pp. 478-485, 2018.

13. N. Coudray, P.S. Ocampo, T. Sakellaropoulos, N. Narula, M .Snuderl, D. Fenyö, A.L. Moreira, N. Razavian, A. Tsirigos, "Classification and mutation prediction from non-small cell lung cancer histopathology images using deep learning", Nature Medicine, Vol. 24, pp. 1559-1567, 2018.

14. G. Yauney, P. Shah, "Reinforcement learning with action-derived rewards for chemotherapy and clinical trial dosing regimen selection", Proceedings of Machine Learning Research, Vol.85, pp. 161-226, 2018.

15. R. Poplin, A.V. Varadarajan, K. Blumer, Y. Liu, M.V. McConnell, G.S. Corrado, L. Peng, D.R. Webster, "Prediction of cardiovascular risk factors from retinal fundus photographs via deep learning", Nature. Biomedical Engineering, Vol.2, pp.158-164, 2018.

16. L. Batyuk, N. Kizilova, "Modeling of dielectric permittivity of the erythrocytes membrane as a three-layer model", In: Development trends in medical science and practice: the experience of countries of Eastern Europe and prospects of Ukraine, Riga, "Baltija Publishing", pp. 18-37, 2018.

\section{ЛІТЕРАТУРА}

1. Yu K., Beam A.L., Kohane I.S. Artificial intelligence in healthcare. Nature Biomedical Engineering. 2018. Vol. 2. P. 719-731.

2. Lynch C.J., Liston C., New machine-learning technologies for computer-aided diagnosis. Nature Medicine. 2018. Vol. 24. P. 1304-1305.

3. Girardi D., Küng J., Kleiser R., Sonnberger M., Johannes D.C., Holzinger T.A. Interactive knowledge discovery with the doctor-in-the-loop: a practical example of cerebral aneurysms research. Brain Informatics. 2016. Vol.3. P. 133-143.

4. Kizilova N. Diagnostics of Coronary Stenosis: Analysis of Arterial Blood Pressure and Mathematical Modeling. In: Biomedical Engineering Systems and Technologies. Springer Series on Communications in Computer and Information Science. Plantier, G., Schulz, T., Fred, A., Gamboa, H. (Eds.). 2015. P. 299-312.

5. Kizilova N. Electromagnetic properties of blood and its interaction with electromagnetic fields". In: Advances in Medicine and Biology. Vol.137. L.V. Berhardt (ed.) NOVA Sci. Publ. 2019. P. 1-74, 2019.

6. Batyuk L., Kizilova N. Dielectric properties of red blood cells for cancer diagnostics and treatment. AS Cancer Biology. 2018. Vol. 2(10). P. 55-60.

7. Batyuk L., Kizilova N., Berest V. Investigation of antiradiation and anticancer efficiency of nanodiamonds on rat erythrocytes. In: Nanomaterials: Application \& Properties, 2017. P. 04NB23.

8. Kingsley P., Taylor E.M. One Health: competing perspectives in an emerging field. Parasitology. 2017. Vol. 144(1). P. 7-14.

9. Zinnstag J., Schelling E., Waltner-Toews D., Whittaker M., Tanner M. (eds) One Health: the theory and practice of integrated health approaches. CAB International. 2015.

10. Azuaje F. Artificial intelligence for precision oncology: beyond patient stratification. Nature Precision Oncology. 2019. Vol. 3. P. 6-11, doi:10.1038/s41698-019-0078-1.

11. Rawat W., Wang Z. Deep convolutional neural networks for image classification: a comprehensive review. Neural Computation. 2017. Vol. 29. P. 2352-2449.

12. Forschner A., Keim U., Hofmann M., Spänkuch I., Lomberg D., Weide B., Tampouri I., Eigentler T., Fink C., Garbe C., Haenssle H.A. Diagnostic accuracy of dermatofluoroscopy in cutaneous melanoma detection: results of a prospective multicentre clinical study in 476 pigmented lesions. British Journal of Dermatology. 2018. Vol.179(2). P. 478-485.

13. Coudray N., Ocampo P.S., Sakellaropoulos T., Narula N., Snuderl M., Fenyö D., Moreira A.L., Razavian N., Tsirigos A. Classification and mutation prediction from non-small cell lung cancer histopathology images using deep learning.Nature Medicine. 2018. Vol. 24. P. 15591567. 
14. Yauney G., Shah P. Reinforcement learning with action-derived rewards for chemotherapy and clinical trial dosing regimen selection. Proceedings of Machine Learning Research. 2018. Vol.85. P. 161-226.

15. Poplin R., Varadarajan A.V., Blumer K., Liu Y., McConnell M.V., Corrado G.S., Peng L., Webster D.R. Prediction of cardiovascular risk factors from retinal fundus photographs via deep learning. Nature. Biomedical Engineering. 2018. Vol.2. P.158-164.

16. Batyuk L., Kizilova N. Modeling of dielectric permittivity of the erythrocytes membrane as a three-layer model. In: Development trends in medical science and practice: the experience of countries of Eastern Europe and prospects of Ukraine, Riga, "Baltija Publishing". 2018. P. 18-37.

Батюк Лілія Василівна - кандидат біологічних наук, дочент кафедри медичної і біологічної фізики та медичної інформатики Харківського начіонального медичного університету, пр. Науки, 4, Харків, Україна 61000; e-mail: liliyabatyuk24@gmail.com; ORCID: 0000-0003-1863-0265.

Batyuk Liliya V. - PhD, Associate Professor of the Department of Medical and Biological Physics and Medical Informatics, Kharkov National Medical University, 4 Nauki Ave., Kharkov, Ukraine 61000; e-mail: liliyabatyuk24@ gmail.com; ORCID: 0000-0003-1863-0265.

Батюк Лилия Васильевна - кандидат биологических наук, дочент кафедры медицинской и биологической физики и медицинской информатики Харьковского начионального медицинского университета, пр. Науки, 4, Харьков, Украина 61000; e-mail: liliyabatyuk24@gmail.com; ORCID: 0000-0003-1863-0265.

Кізілова Наталія Миколаӥвна - доктор фізико-математичних наук, професор кафедри прикладної математики, Харківський національний університет імені В. Н. Каразіна, майдан Свободи, 4, Харків-22, Україна, 61022; e-mail: n.kizilova@gmail.com; ORCID: 0000-0001-99817616.

Kizilova Natalya M. - DSc, professor of the Department of Applied Mathematics, V. N. Karazin Kharkiv National University, 4 Svobody Sq., Kharkiv, 61022,Ukraine; e-mail: n.kizilova@gmail.com; ORCID: 0000-0001-9981-7616.

Кизилова Наталья Николаевна - доктор физ.-мат. наук, профессор кафедры прикладной математики, Харьковский начиональный университет имени В.Н. Каразина, площадь Свободы, 4, Харьков-22, Украина, 61022; e-mail: n.kizilova@gmail.com; ORCID: 0000-0001-9981-7616. 